Original article

\title{
Bamboo thickets alter the demographic structure of Euterpe edulis population: A keystone, threatened palm species of the Atlantic forest
}

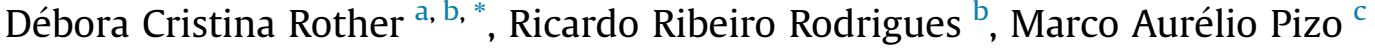 \\ ${ }^{a}$ UNESP - Universidade Estadual Paulista, Programa de Pós-graduação em Biologia Vegetal, Av. 24 A, 1515, 13506-900, Rio Claro, São Paulo, Brazil \\ ${ }^{\mathrm{b}}$ ESALQ - Escola Superior de Agricultura Luiz de Queiroz, USP - Universidade de São Paulo, Departamento de Ciências Biológicas, Laboratório de Ecologia e \\ Restauração Florestal, Av. Pádua Dias, 11, Caixa Postal 9, Piracicaba, CEP 13418-900, São Paulo, Brazil \\ ${ }^{\mathrm{c}}$ UNESP - Universidade Estadual Paulista, Departamento de Zoologia, Av. 24 A, 1515, 13506-900, Rio Claro, São Paulo, Brazil
}

\section{A R T I C L E I N F O}

\section{Article history:}

Received 19 December 2014

Received in revised form

24 October 2015

Accepted 27 November 2015

Available online 28 December 2015

\section{Keywords:}

Palm heart

Arrested regeneration

Demographic bottleneck

Recruitment limitation of later stages

Guadua tagoara

\begin{abstract}
A B S T R A C T
The rapid spread of bamboos can strongly affect forest structure by interfering plant regeneration and reducing local biodiversity. Considering that bamboos exert a negative influence on the plant community, our main goal was to investigate how this influence manifests at the population level. We compared the demographic structure of the threatened palm Euterpe edulis between bamboo and non-bamboo dominated patches within the Atlantic forest. In the study site, the native bamboo Guadua tagoara has created a marked patchiness and heterogeneity in the vegetation. Plots were set up randomly in bamboo and non-bamboo patches and the heights of all E. edulis individuals were measured. Data from canopy openness and litter depth were collected for both patches. Greater number of E. edulis was recorded in bamboo patches. However, frequency distribution of the height classes differed between patches revealing a predominance of seedling and sapling I classes in bamboo patches, in comparison to a more evenly distribution of height classes in non-bamboo patches. The canopy in bamboo patches was more open and the litter depth was thicker. Our analyses evidenced $G$. tagoara is functioning as a demographic bottleneck of natural population of E. edulis by arresting its later stages of regeneration and in high densities that bamboos may limit recruitment of this palm species.
\end{abstract}

๑) 2015 Elsevier Masson SAS. All rights reserved.

\section{Introduction}

Bamboo establishment within areas of tropical forest can occur rapidly due to its naturally invasive ecology, which is facilitated by vegetative reproduction and occur even when the bamboo is native to the forest (Wong, 1991). The rapid spread of bamboos can strongly affect forest structure, either through interfering with plant regeneration and reducing local biodiversity (Lima, 2007; Lima et al., 2012; Oliveira-Filho et al., 1994; Rother, 2006; Rother et al., 2013a) or by altering the structure of vegetation (Fantini and Guries, 2007; Guilherme et al., 2004; Lima, 2007; Lima et al., 2012; Oliveira-Filho et al., 1994; Rother, 2006; Rother et al., 2013a; Tabarelli and Mantovani, 1999).

Bamboo promotes structural changes in vegetation through

\footnotetext{
* Corresponding author. ESALQ - Escola Superior de Agricultura Luiz de Queiroz, USP - Universidade de São Paulo, Departamento de Ciências Biológicas, Laboratório de Ecologia e Restauração Florestal, Av. Pádua Dias, 11, Caixa Postal 9, Piracicaba, CEP 13418-900, São Paulo, Brazil.

E-mail address: deborarother@gmail.com (D.C. Rother).
}

either direct damage to other plants or indirectly via impacts on regenerating plants through changes in the forest microclimate and increased litter deposition (Araujo, 2008). As a consequence of its establishment, bamboo may influence the vegetation in different ways: affecting the abundance of seeds entering a site via dispersal mechanisms (Rother et al., 2009), the regeneration of tree species (Carvalho, 1997; Oliveira-Filho et al., 1994; Fantini and Guries, 2007), the growth of trees (Oliveira-Filho et al., 1994) and subsequently forest succession more generally (Griscom and Ashton, 2003; Lima, 2007).

Most of the studies involving bamboo dominance of tropical forests are concentrated within a few sites in the Amazon and Atlantic Forests. Oliveira (2000) found that larger trees were the least common size class present within forests dominated by Guadua weberbaueri in the northern state of Acre. Also in north Brazil Silveira (2000) noted that local floristic composition was reduced to almost $40 \%$ of the initial species richness as a result of G. weberbaueri colonization.

In the Atlantic forest, which is threatened by habitat loss and fragmentation (Ribeiro et al., 2009), researchers and 
conservationists see Guadua tagoara (Nees) Kunth and other bamboo species as a major threat (Araujo, 2008). In certain protected areas, bamboo presence is considered to be one of the major factors related to the reduction of species richness (Lima et al., 2012). Despite being a native species, concerns exist because evidence that G. tagoara populations are expanding (Alves, 2007). At sites where $G$. tagoara naturally occurs, changes in forest dynamics have been observed when the species is able to find suitable conditions to establish and dominate (Alves, 2007; Fantini and Guries, 2007; Morokawa, 2008).

Due to the fact that it is a pioneer species and can quickly occupy disturbed areas (Judziewicz et al., 1999), some authors associate the current abundance of $G$. tagoara to anthropogenic disturbances, such as the extraction of palm heart from Euterpe edulis, a usually dominant tree species in non-disturbed areas (Araujo, 2008; Fantini and Guries, 2000).

Bamboo dominance and its subsequent effect on plant and bird communities is well studied in Carlos Botelho state park (Lima et al., 2012; Rother et al., 2009, 2013a, 2013b). Recent research indicates that seed rain is not greatly altered by the presence of G. tagoara (Rother et al., 2009), which, however, exerts a negative influence on seedling establishment, a crucial stage for plant regeneration (Rother, 2006; Rother et al., 2013a). Interestingly, this finding did not apply to seedlings of E. edulis, which were found to be present in greater density within bamboo dominated patches (Rother, 2006). Bamboo effects upon the early recruitment of nonbamboo species were thus demonstrated to be patchy and speciesspecific, with patches of bamboo dominated succession exerting a far-reaching influence over the heterogeneity of plant species composition and abundance (Rother et al., 2013a).

E. edulis is the dominant species of palm in the understory of the Atlantic forest. It is also threatened by illegal overexploitation (Galetti and Fernandez, 1998). Within Carlos Botelho State Park, E. edulis populations are reducing rapidly as a result of this intense exploitation (Muler et al., 2014; Rother et al., 2009). Bamboo expansion has also been linked to this exploitation (Araujo, 2008, Fantini and Guries, 2000).

E. edulis has characteristics that amplify its ecological importance in the forest ecosystem. Its historic abundance lends the species a central place in the vegetation structure and dynamics of the Atlantic Forest, rendering it a priority species within forest management plans and conservation efforts. It also plays a key role concerning the attraction and retention of seed dispersers by annually producing large quantities of fruit, most crucially within the food shortage period (Castro et al., 2007; Fadini et al., 2009).

As the only species in the local plant community which did not suffer any limitation by bamboo in the early stages of the regeneration cycle, the study of E. edulis population structure in bamboo dominated forest has the potential to function as a model for evaluating the consequences of bamboo thickets on forest dynamics (Rother et al., 2013a).

In the literature, there are plenty of studies that investigate the effects of a plant species population on other plant species population (Wang and Augspurger, 2004, 2006). Nonetheless, remain scarce studies focusing on the influence of bamboo species on plant populations. Considering that bamboos exert a negative influence on the plant community, our main goal was to investigate how this influence manifests at the population level. We compared the demographic structure of $E$. edulis between bamboo and non-bamboo dominated patches within the Brazilian Atlantic forest where G. tagoara has created a marked patchiness and heterogeneity in the vegetation (Muler et al., 2014; Rother et al., 2013a).

The demography of natural populations of $E$. edulis has been well studied (Melito et al., 2014; Meyer and Dornelles, 2009; Raupp et al., 2009; Reis et al., 2000; Silva, 1991; Silva et al., 2009). We are interested here, however, in evaluating whether different habitats characterized by the extent of bamboo dominance can lead to different demographic structures of E. edulis. Also, we are interested in characterize both patches regarding canopy openness and litter depth. After considering the pre-existing literature, we hypothesized that bamboo dominated patches would show an arrested recruitment of $E$. edulis in the later stages due to a possible physical barrier to the growth of this palm. Finally, we discuss the influence of bamboo dominance and microhabitat characteristics on the future of E. edulis populations in the Atlantic forest.

\section{Materials and methods}

\subsection{Study site}

The study took place in a 10-ha permanent research plot located within Carlos Botelho state park (Fig. 1), a reserve of over 37,000 ha of well-preserved Atlantic rain forest (sensu Morellato and Haddad, 2000) located in the state of São Paulo, SE Brazil. The study site (24 ${ }^{\circ}$ $10^{\prime} \mathrm{S}, 47^{\circ} 56^{\prime} \mathrm{W}$; 350-450 $\mathrm{m}$ a.s.l.) is covered by tall $(20-30 \mathrm{~m})$ lowland old-growth forest with an opened understory. During the study period, the mean temperature was $21.1^{\circ} \mathrm{C}$ (range $17.4-25.2^{\circ}$ C), and the site received $3384 \mathrm{~mm}$ of rainfall. Rains are well distributed throughout the year, but the rainiest and hottest season occurs from December to March.

Approximately 3 ha of the study area is covered by G. tagoara which form scattered patches throughout the plot. G. tagoara is a perennial plant with woody stems 8-15 $(-20) \mathrm{m}$ high, $5-10 \mathrm{~cm}$ diameter, erect at the base but scandent at the apex. Stems have spines on nodes, more developed in the lower nodes, hollow internodes, and deciduous leaves sometimes persistent in the basal nodes. The genus Guadua is widely distributed throughout the Neotropics and contains around 30 species (Londoño, 1998; Young and Judd, 1992). G. tagoara occurs within the Brazilian Atlantic forest in areas of secondary growth (Fantini and Guries, 2007). The reproductive behavior of this species needs further studies, but there are indications that the populations die after fruiting period (Alves, 2007).

In non-bamboo dominated patches vegetation is characterized by the presence of trees, woody lianas and epiphytes in an abundance that differentiate them from other vegetation formations (Dias, 2005; Veloso and Oliveira Filho, 1992). It is similarly covered by a tall $(20-30 \mathrm{~m})$ lowland old-growth forest with an opened understory where the palms E. edulis (269.8 individuals.ha-1; unpubl. data) and Geonoma spp., and arborescent ferns (Cyatheaceae) are common. Myrtaceae, Lauraceae, Rubiaceae, Fabaceae and Sapotaceae are the richest plant families (Dias, 2005).

\subsection{Species}

E. edulis (hereafter Euterpe) is one of the most abundant understory tree species in the Atlantic Forest, occurring at an approximate density of 224 individuals.ha ${ }^{-1}$ when counting trees with diameter at breast height $(\mathrm{DBH})>4.8 \mathrm{~cm}$ (Rodrigues, 2006). Individual palms produce $1-5$ infructescences annually bearing on average over 3000 fruits each (Mantovani and Morellato, 2000). Euterpe fruits are globose drupes containing a single rounded seed which averages $12 \mathrm{~mm}$ in diameter (Pizo and Vieira, 2004). Fruits are eaten by a variety of animals, including birds and mammals, which disperse the seeds (Galetti et al., 1999).

\subsection{Data collection}

\subsubsection{Euterpe demography}

Twenty $10 \times 10$ square plots were set up randomly in bamboo 


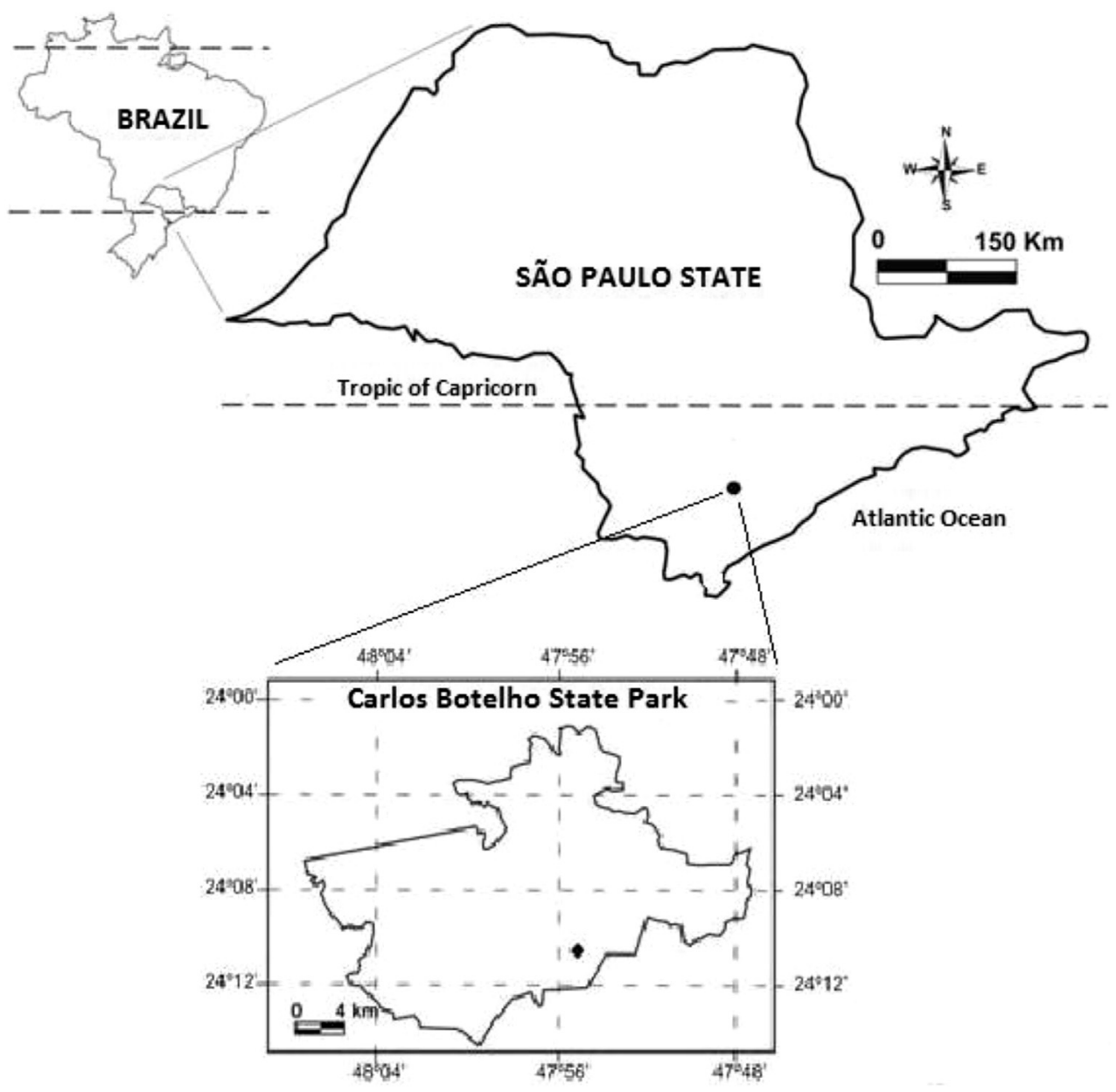

Fig. 1. Study site at Carlos Botelho State Park, Sete Barras municipality, São Paulo State, Brazil. The point represents the location of Permanent Plot.

and non-bamboo patches, amounting to a total of 40 plots. The heights of all Euterpe individuals within the plots were measured at the apex, i.e. the point where the youngest leaf intersects with the stem. Following the classification of Silva (1991) and Reis (1995), with adaptations, individuals were assigned to one of the following classes based on their heights: seedling $(\leq 0.30 \mathrm{~m})$, sapling I $(0.31 \mathrm{~m}-1.00 \mathrm{~m})$, sapling II $(1.01 \mathrm{~m}-2.00 \mathrm{~m})$, sapling III $(2.01 \mathrm{~m}-6.00 \mathrm{~m})$, and adult $(\geq 6.01 \mathrm{~m}$ or with reproductive signal, i.e., scar or drooping of inflorescences and infructescences under the plant). Heights were measured with a measuring tape, except to the adults that were estimated using a straight stick of $2 \mathrm{~m}$ length. Those data were collected in July 2005.

\subsubsection{Microhabitat characteristics}

To characterize bamboo (hereafter B) and non-bamboo (hereafter NB) patches we measured for canopy openness and litter depth in both patches. Canopy openness is a surrogate measure for the amount of light reaching the forest floor, an important factor for plant performance, especially during early recruitment (Swaine, 1996). Litter depth, in turn, has been demonstrated to influence the predation and germination of seeds, and thus seedling establishment rates (Molofsky and Augspurger, 1992; Schupp, 1988). Data from canopy openness and litter depth were collected in 40 points at each patch totaling 80 points in the permanent plot to characterize the microhabitats. Canopy openness was estimated above each point with a spherical densiometer (Forestry Suppliers Inc.; Lemmon, 1957). Four densiometer readings were made facing outward at each side of each point and averaged for analyses. Litter depth was estimated by pinching the leaf litter with a slender stick and counting the number of leaves pinched. Five pinches were made in each point and the average was used for analyses.

\subsection{Data analyses}

To study population structure of Euterpe we used the statistical parameters: mean, confidence interval (confidence level at 95\%) and variance. To compare the abundance and density of Euterpe between $\mathrm{B}$ and NB patches we used the F-test, and to evaluate frequency differences among height classes between patches we performed the Kolmogorov-Smirnov test.

To characterize the B and NB patches we firstly performed a Spearman Correlation to prevent collinearity between variables. Finally we compared each variable between patches using a Man$\mathrm{n}$-Whitney test. All analyses were performed through using the PAST program (Hammer et al., 2001).

\section{Results}

\subsection{Euterpe demography}

A total of 285 and 724 Euterpe individuals were sampled within the non-bamboo and bamboo patches respectively. In bamboo patches seedling abundance was considerably greater than nonbamboo patches. Seedlings within bamboo patches represented 
80.25\% (581 seedlings) of all height classes recorded, whereas in non-bamboo patches seedlings represented only 33.68\% (96 seedlings) of all height classes. Descriptive data is provided in Table 1. Variance of Euterpe population varied significantly in NB patches, resulting in a greater variation in height classes within the Euterpe population $(\mathrm{F}=10.92, \mathrm{p}<0.001)$ (Table 2 ).

Frequency distribution of the height classes differed between patches $\left(D_{\max }=0.46 ; p<0.01\right)$, revealing a predominance of young individuals in the seedling and sapling I classes in bamboo patches, in comparison to a more evenly distribution of height classes in non-bamboo patches (Fig. 2). In short, bamboo presence exerted an important influence on the height classes of Euterpe.

\subsection{Microhabitat characteristics}

The variables of canopy openness and litter depth were not significantly correlated $\left(r_{s}=0.14 ; \mathrm{p}=0.20 ; \mathrm{n}=80\right)$. Overall, the canopy in bamboo patches was more open $(U=466, p=0.001$, $\mathrm{n}=40)$, and the litter depth was thicker $(\mathrm{U}=509 ; \mathrm{p}=0.005$; $\mathrm{n}=40$ ) (Fig. 3A and B, respectively).

\section{Discussion}

Populations in both patches showed the expected reverse Jshaped curves with certain small deviations from this shape (Fig. S1). These small differences may have resulted from past harvests of palm heart at the studied site (Muler et al., 2014). The reverse J-shaped curve is usually taken as an indicator of selfreplacing populations but this is discussed by Virillo et al. (2011). These authors evaluated populations over time and found that not all species with reverse J-shaped curves are effectively stable or increasing in population. They also conclude that for management purposes it is necessary consider the variation on demographic rates over time and the factors that influence this variation.

Natural populations of Euterpe typically have a pyramid-shaped demographic structure with a large base of seedlings and saplings and a small number of reproductive individuals (Reis et al., 2000). Despite this, in our study bamboo presence clearly lead to differences in Euterpe height class distribution. Individuals from the early recruitment stage (i.e, seedling and sapling I) were the most common individuals in bamboo patches, indicating that there is a potential seedling bank and juveniles up to $1.0 \mathrm{~m}$ tall for forest regeneration. The typical reproductive strategy of Euterpe includes the maintenance of a large seedling bank (Reis et al., 1996; Raupp et al., 2009).

Within bamboo dominated patches, distinctive physiognomic characteristics can limit the seed rain of Euterpe, most likely because frugivores seem to be the least common fauna by dietary category (Rother et al., 2013b). On the other hand, bamboo provides suitable conditions for germination and seedling establishment as previously reported by Rother et al. (2013a). In developing a manipulative experiment, these authors were able to establish that

Table 1

Descriptive data for Euterpe edulis populations in each height classes at bamboo (B) and non-bamboo dominated patches (NB) in Carlos Botelho State Park, Sete Barras municipality, São Paulo, Brazil.

\begin{tabular}{lrrrlll}
\hline Height classes & \multicolumn{2}{l}{ Abundance } & & \multicolumn{2}{l}{ Density $\left(\mathrm{m}^{2}\right)$} \\
\cline { 2 - 3 } \cline { 5 - 6 } & $\mathrm{B}$ & $\mathrm{NB}$ & & $\mathrm{B}$ & $\mathrm{NB}$ \\
\hline Seedling & 581 & 96 & & 0.291 & 0.048 \\
Sapling I & 123 & 121 & & 0.062 & 0.061 \\
Sapling II & 7 & 23 & & 0.004 & 0.012 \\
Sapling III & 13 & 37 & & 0.007 & 0.019 \\
Adult & 0 & 8 & & 0 & 0.004 \\
\hline
\end{tabular}

Table 2

Parameters for population structure for Euterpe edulis at bamboo (B) and nonbamboo dominated patches (NB) in Carlos Botelho State Park, Sete Barras municipality, São Paulo, Brazil.

\begin{tabular}{lll}
\hline Parameters & B & NB \\
\hline Abundance & 724 & 285 \\
Mean & 0.29 & 1.05 \\
95\% Confidence interval & $0.25-0.32$ & $0.87-1.23$ \\
Variance & 0.22 & 2.41 \\
\hline
\end{tabular}

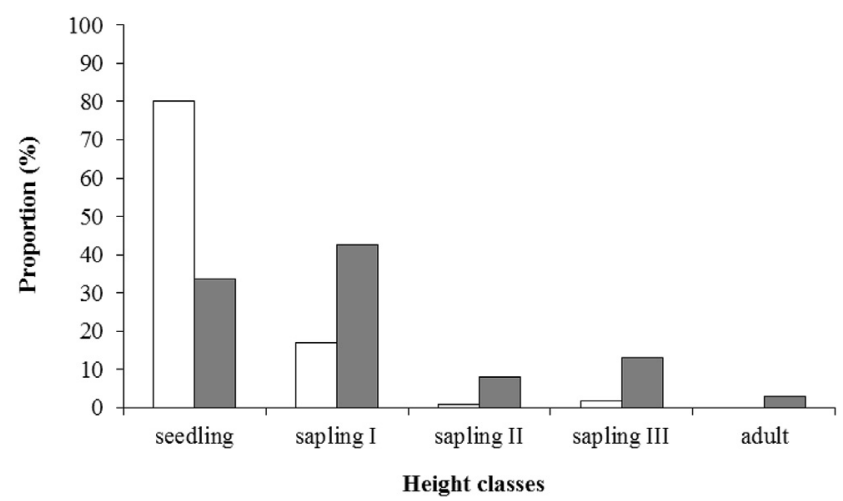

Fig. 2. Frequency distribution of Euterpe edulis in height classes at bamboo (white bars, $\mathrm{n}=724$ ) and non-bamboo dominanted patches (grey bars, $\mathrm{n}=285$ ).

Euterpe emergence and seedling survival is greater within bamboo dominated patches.

Non-bamboo patches naturally receive a greater density of Euterpe seeds (Rother et al., 2013a). Nevertheless, if dispersal is not a problem for Euterpe seeds in non-bamboo sites, the authors contended that its success in early recruitment is then strongly constrained by post-dispersal mortality factors in these patches, especially seed removal and predation. In the literature, some authors found that action of fungi due to humidity (Janzen, 1970; Connell, 1971), the fall of canopy trees leaves (Cintra, 1997; Svenning, 2001; Raupp and Cintra, 2010) and the percentage of rocky outcrop (Raupp et al., 2009) are also factors that limit the development of seedlings.

Despite the seedling recruitment is very variable through time, it is worth noting that there is a kind of complement of height classes between environments. Although smaller classes were less represented within the Euterpe population in non-bamboo patches, these patches contained a larger stock of individuals with the potential to reach adulthood. According to our results, after the critical seed-seedling stage, non-bamboo sites seems to be suitable for the successful recruitment of Euterpe.

A distinct pattern was observed within bamboo patches, due to the fact that the tangled $G$. tagoara stems form thickets that act as a physical barrier preventing Euterpe individuals from reaching the later stages of growth and regeneration. In summary, Euterpe within bamboo dominated patches must overcome significant barriers to reach the reproductive stage, and thus ensure any continued regeneration of the population. Other studies have confirmed this pattern, attributing these results to bamboo mechanical damage on the plants (Lima et al., 2012; Griscom and Ashton, 2003). Griscom and Ashton (2003) established that Guadua sarcocarpa dominated patches within the Peruvian Amazon reduce the survival and recruitment of all other plant species, as well as causing physical damage via the fall of culms that fold up on themselves. Using the same permanent research plot employed by this study, Lima et al. (2012) recorded that G. tagoara patches contained a lower density of adult trees $(\mathrm{DBH}>5 \mathrm{~cm})$ and greater 

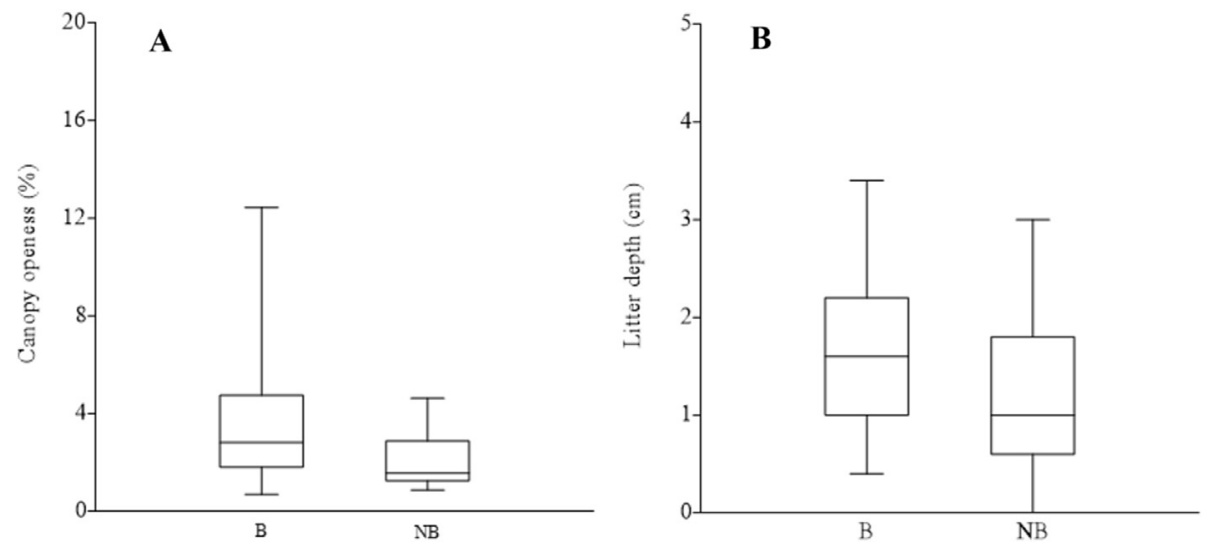

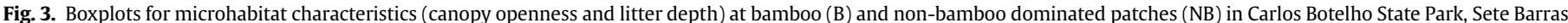

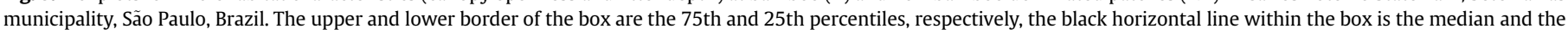
error bars are the 10th and 90th percentiles.

concentration of small-sized trees. Authors relate these differences to higher mortality rates, lower rates of recruitment, mechanical damage caused by culm fall and a higher frequency of resprouting individuals (of other plant species) within bamboo dominated patches.

Euterpe is a palm of the Atlantic Forest and Cerrado Biomes (Martinelli and Moraes, 2013) that occurs predominantly in soils with high water availability (Brancalion et al., 2012). At the permanent plot the soils occupied by bamboos are predominantly more fertile and clayey, whilst the soils in non-bamboo dominated plots are typically sandy loams (Lima et al., 2012). As clay soils have very small, electrically bonded particles, the micropores between them usually retain more water (Osman, 2013). These soil differences could offer an alternative explanation as to why Euterpe form a higher seedling bank in bamboo dominated patches.

Microhabitat characteristics (Vásquez-Yánes and OrozcoSegovia, 1993) and interspecific interactions (Dirzo and Dominguez, 1986) are able to influence seed germination and, consequently, the differential establishment of the species in the environments. Establishment limitation has been reported as a result of high rates of seed predation (Fleury and Galetti, 2006; Santos and Tellería, 1994) and reduction or absence of suitable sites for the establishment (Bruna, 2002; Jordano et al., 2004; Meiners et al., 2002). In this case, abiotic variables such as light and litter can affect the establishment and recruitment pattern of species in the forest. Light availability is known to be an important factor for growth in tropical plants (Howe et al., 1985; Swaine, 1996), whilst litter characteristics can influence patterns of seed predation or seed germination (Molofsky and Augspurger, 1992; Schupp, 1988).

In the current study, understory under bamboos had a higher light incidence. This may negatively influence the germination and establishment of shade tolerant understory species, as Euterpe. Despite being a shade tolerant understory species, Euterpe still requires the presence of a forest microhabitat with sufficient light for successful regeneration and initial growth (Klein, 1974). Euterpe can benefit from small gaps appearance for regeneration (Nakazono et al., 2001). Thus, contrary to our hypothesis, bamboo dominated patches offered suitable lighting conditions for the initial recruitment of Euterpe seedlings. Light is a central limiting factor on the general growth and presence of forest palms. A higher investment in vertical growth can lead to a vertical position in the forest canopy that provides the greater benefits of increased illumination (Alves et al., 2004). This may be related to the greater number of adults found at non bamboo patches. Similarly, litter depth was greater upon soil from within bamboo dominated patches, a characteristic that can also affect seed germination and seedling establishment. This did not, however, exert any statistically significant influence upon the early regeneration of Euterpe in bamboo dominated patches.

According our results, G. tagoara is functioning as a demographic bottleneck of the later stages of Euterpe regeneration, which corroborates with our initial hypothesis. These patches in the forest are changing the demographic structure of natural population of Euterpe through arresting its regeneration cycle.

\section{Conclusions}

Natural populations of Euterpe have dependence of a large population, as the base of the demographic structure with a large base of juvenile plants (especially, seedlings and saplings) and a small number of reproductive individuals (Reis, 1995; Reis et al., 2000). However, survival in later stages is crucial for predicting patterns of Euterpe population persistence in tropical forests.

As the adults are the reservoir of genetic structure, the demographic population of this palm species is a matter of concern because, besides the presence of bamboo, illegal harvesting of reproductive adults frequently occurs in the study area. This illegal activity, however, creates gaps that favor bamboo proliferation (Fantini and Guries, 2007). Here, we have a complex system that deserve more studies because if the density of Euterpe adult's decreases with time as a consequence of both arrested regeneration in the later stages and the perpetuation of the bamboo dominance, recruitment limitation within bamboo patches tends to enhance.

Recruitment limitation has also negative consequences for ecological interactions between Euterpe and species that depend on it for feed. In a changing world, more important than focusing on a single species, it is important to conserve networks of interacting species and rethink management options to maintain the community functions.

\section{Author contributions}

Conceived and designed the experiments: DCR, RRR, MAP. Performed the experiments: DCR. Analyzed the data: DCR, MAP. Contributed reagents/materials/analysis tools: RRR. Wrote the manuscript: DCR, RRR, MAP. 


\section{Acknowledgments}

We thank the staff at Carlos Botelho State Park for allowing our fieldwork. We are especially grateful to Luciana Spinelli Araujo and Paulo C. Teixeira for their help in the data collection. DCR received financial support from FAPESP (03/11073-7), RRR received financial from Biota project also supported by FAPESP (99/09635-0). MAP received a research grant from $\mathrm{CNPq}$.

\section{Appendix A. Supplementary data}

Supplementary data related to this article can be found at http:// dx.doi.org/10.1016/j.actao.2015.11.008.

\section{References}

Alves, G.T.R., 2007. Aspectos da história de vida de Guadua tagoara (Nees) Kunth (Poaceae: Bambuseae) na Serra dos Órgãos, RJ.

Alves, L., Martins, F., Santos, F., 2004. Allometry of a neotropical palm, Euterpe edulis Mart. Acta Bot. Bras. 18, 369-374.

Araujo, L.S., 2008. Padrões e condicionantes da dinâmica da paisagem na floresta com bambus do Parque Estadual Intervales, SP. Thesis. Escola Superior de Agricultura Luiz de Queiroz/USP, Piracicaba, SP.

Brancalion, P.H.S., Vidal, E., Lavorenti, N.A., Batista, J.L.F., Rodrigues, R.R., 2012. Soilmediated effects on potential Euterpe edulis (Arecaceae ) fruit and palm heart sustainable management in the Brazilian Atlantic Forest. For. Ecol. Manag. 284, 78-85. http://dx.doi.org/10.1016/j.foreco.2012.07.028.

Bruna, E.M., 2002. Effects of forest fragmentation on Heliconia acuminata seedling recruitment in central Amazonia. Oecologia 132, 235-243.

de Carvalho, L.M.T., 1997. Dinâmica de clareiras em uma floresta de nuvem na Serra do Ibitipoca, Minas Gerais. Master thesis. Universidade Federal de Lavras, Lavras.

Castro, E.R., Galetti, M., Morellato, L.P., 2007. Reproductive phenology of Euterpe edulis (Arecaceae) along a gradient in the Atlantic rainforest of Brazil. Aust. J. Bot. 55, 725-735.

Cintra, R., 1997. Spatial distribution and foraging tactics of tyrant flycatchers in two habitats in the Brazilian Amazon. Stud. Neotrop. Fauna Environ. 32, 17-27.

Connell, J.H., 1971. On the role of natural enemies in preventing competitive exclusion in some marine animals and in rain forest trees. In: den Boer, P. Gradwell, G.R. (Eds.), Dynamics of Populations. Center for Agricultural Publishing and Documentation, Wageningen, pp. 298-310.

Dias, A.C., 2005. Composição florística, fitossociologia, diversidade de espécies arbóreas e comparação de métodos de amostragem na Floresta Ombrófila Densa do Parque Estadual Carlos Botelho/SP - Brasil. Thesis. Escola Superior de Agricultura Luiz de Queiroz, Universidade de São Paulo, Piracicaba.

Dirzo, R., Dominguez, A.C., 1986. Seed shadows, seed predation and the advantages of dispersal. In: Estrada, A., Fleming, T.H. (Eds.), Frugivores and Seed Dispersal. Dr. W. Junk Publishers, The Hague, Netherlands, pp. 237-249.

Fadini, R.F., Fleury, M., Donatti, C.I., Galetti, M., 2009. Effects of frugivorous impoverishment and seed predators on the recruitment of a keystone palm. Acta Oecol. 35, 188-196.

Fantini, A.C., Guries, R.P., 2000. Guadua tagoara (taquaruçu): uma espécie invasiva da Mata Atlântica. In: Sexto Congresso e Exposição sobre Florestas, Porto Seguro. Resumos Técnicos. Instituto Ambiental Biosfera, Rio de Janeiro, pp. 136-138.

Fantini, A.C., Guries, R.P., 2007. Forest structure and productivity of palmiteiro (Euterpe edulis Martius) in the Brazilian Mata Atlântica. For. Ecol. Manag. 242, 185-194. http://dx.doi.org/10.1016/j.foreco.2007.01.005.

Fleury, M., Galetti, M., 2006. Forest fragment size and microhabitat effects on palm seed predation. Biol. Conserv. 131, 1-13. http://dx.doi.org/10.1016/ j.biocon.2005.10.049.

Galetti, M., Fernandez, J.C., 1998. Palm heart harvesting in the Brazilian Atlantic forest: changes in industry structure and the illegal trade. J. Appl. Ecol. 35, 294-301.

Galetti, M., Zipparro, V.B., Morellato, L.P.C., 1999. Fruiting phenology and frugivory on the palm Euterpe edulis in a lowland Atlantic Forest of Brazil. Ecotropica 5, $115-122$.

Griscom, B.W., Ashton, P.M.S., 2003. Bamboo control of forest succession: Guadua sarcocarpa in Southeastern Peru. For. Ecol. Manag. 175 (1-3), 445-454. http:// dx.doi.org/10.1016/S0378-1127(02)00214-1.

Guilherme, F.A.G., Oliveira-Filho, A.T., Appolinário, V., Bearzoti, E., 2004. Effects of flooding regime and woody bamboos on tree community dynamics in a section of tropical semideciduous forest in South-Eastern Brazil. Plant Ecol. 174, 19-36.

Hammer, O., Harper, D.A.T., Ryan, P.D., 2001. PAST: paleontological statistics software package for education and data analysis. Palaeontol. Electron. 4 (1), 9.

Howe, H.F., Schupp, E.W., Westley, L.C., 1985. Early consequences of seed dispersal for a neotropical tree (Virola surinamensis). Ecology 66, 781-791.

Janzen, D.H., 1970. Herbivores and the number of tree species in tropical forests. Am. Nat. 104, 501-528.

Jordano, P., Pulido, F., Arroyo, J., Luis, J., Patricio, G., 2004. Procesos de limitación demográfica. In: Ecología Del Bosque Mediterráneo En Un Mundo Cambiante, pp. 229-248.

Judziewicz, E.J., Clark, L.G., Londoño, X., Stern, M.J., 1999. American Bamboos. Smithsonian Institution, Washington and London.

Klein, R.M., 1974. Euterpe edulis Martius - Observações ecológicas. In: Reitz, R. (Ed.), Palmeiras. Flora ilustrada catarinense Palm 102-105.

Lemmon, P.E., 1957. A new instrument for measuring forest overstory density. J. For. $55,667-668$.

Lima, R.A.F., 2007. Regime de distúrbio e dinâmica da regeneraçao natural da Floresta Pluvial Atlântica Submontana.

Lima, R.A.F., Rother, D.C., Muler, A.E., Lepsch, I.F., Rodrigues, R.R., 2012. Bamboo overabundance alters forest structure and dynamics in the Atlantic forest hotspot. Biol. Conserv. 147, 32-39. http://dx.doi.org/10.1016/ j.biocon.2012.01.015.

Londoño, X., 1998. A decade of observations of a Guadua angustifolia plantation in Colombia. J. Am. Bamboo Soc. 12, 37-43.

Mantovani, A., Morellato, L.P.C., 2000. Fenologia da floração, frutificação, mudança foliar e aspectos da biologia floral do palmiteiro. In: Reis, M.S., Reis, A. (Eds.), Euterpe edulis Martius (palmiteiro): biologia, conservação e manejo. Herbário Barbosa Rodrigues, Itajaí, Brazil, pp. 23-38.

Martinelli, G., Moraes, M.A., 2013. Livro vermelho da flora do Brasil, first ed. Instituto de Pesquisas Jardim Botânico do Rio de Janeiro, Rio de Janeiro.

Meiners, S.J., Pickett, S.T.A., Handel, S.N., 2002. Probability of tree seedling establishment changes across a forest-old field edge gradient. Am. J. Bot. 89, 466-471.

Melito, M.O., Faria, J.C., Amorim, A.M., Cazetta, E., 2014. Demographic Structure of a Threatened Palm (Euterpe edulis Mart.) in a Fragmented Landscape of Atlantic Forest in Northeastern Brazil, 28, pp. 249-258.

Meyer, F., Dornelles, S., 2009. Demografia do palmiteiro Euterpe edulis (Arecaceae) na floresta ombrófila densa de terra baixas em regeneração, na região da Vila da Glória. Revista Saúde e Ambiente, São Francisco do Sul, pp. 7-13.

Molofsky, J., Augspurger, C.K., 1992. The effect of leaf litter on early seedling establishment in a tropical forest. Ecology 73, 68-77.

Morellato, L.P.C., Haddad, C.F.B., 2000. Introduction: the Brazilian Atlantic forest. Biotropica 32, 786-792.

Morokawa, M.J., 2008. Influência do bambu Guadua tagoara (Nees) Kunth sobre a regeneração natural no Parque Nacional da Serra dos Órgãos (RJ). Monography, Universidade Rural do Rio de Janeiro, Seropédica, RJ.

Muler, A., Rother, D., Brancalion, P., 2014. Can overharvesting of a non-timberforest-product change the regeneration dynamics of a tropical rainforest? The case study of Euterpe edulis. For. Ecol. Manag. 324, 117-125. http://dx.doi.org/ 10.1016/j.foreco.2013.09.001.

Nakazono, E.M., Costa, M.C., Futatsugi, K., Paulilo, M.T.S., 2001. Crescimento inicial de Euterpe edulis Mart. em diferentes regimes de luz. Rev. Bras. Bot. 24, 173-179.

Oliveira, A.C.A., 2000. Efeitos do bambu Guadua weberbaueri Pilger sobre a fisionomia e estrutura de uma floresta no sudoeste da Amazônia. Thesis. Instituto Nacional de Pesquisas da Amazônia, Universidade do Amazonas, Manaus.

Oliveira-Filho, A.T., de Vilela, E.A., Gavilanes, M.L., Carvalho, D.A., 1994. Effect of flooding regime and understorey bamboos on the physiognomy and tree species composition of a tropical semideciduous forest in southeastern Brazil. Plant Ecol. 113, 99-124. http://dx.doi.org/10.1007/BF00044229.

Osman, K.T., 2013. Physical properties of forest soils. In: Forest Soils. Properties and Management. Springer International Publishing, Cham, pp. 19-29. http:// dx.doi.org/10.1007/978-3-319-02541-4.

Pizo, M.A., Vieira, E.M., 2004. Palm harvesting affects seed predation of Euterpe edulis, a threatened palm of the Brazilian Atlantic forest. Braz. J. Biol. 64, 669-676.

Raupp, S.V., Cintra, R., 2010. Efeito da heterogeneidade da floresta na composição de espécies de palmeiras na Amazônia Central. Rev. Biol. Neotrop. 7, 13-26.

Raupp, S., Brack, P., Leite, S., de, C., 2009. Aspectos demográficos de palmiteiro (Euterpe edulis Mart.) em uma área da Floresta Atlântica de Encosta em Maquiné. Iheringia, Série Botânica, Rio Grande do Sul, pp. 57-61.

Reis, A., 1995. Dispersão de sementes de Euterpe edulis Martius (Palmae) em uma floresta ombrófila densa montana da encosta Atlântica em Blumenau, SC. Universidade Estadual de Campinas.

Reis, A., Kageyama, P.Y., Reis, M.S., Fantini, A.C., 1996. Demografia de Euterpe edulis Martius (Arecaceae) em Floresta Ombrófila Densa, em Blumenau (SC). Sellowia 45-58, 13-45.

Reis, M.S., dos Fantini, A.C. Nodari, R.O., Reis, A., Guerra, M.P., Mantovani, A, 2000. Management and conservation of natural populations in Atlantic rain forest: the case study of palm heart (Euterpe edulis Martius). Biotropica 32, 894-902. http://dx.doi.org/10.1646/0006-3606(2000)032[0894:MACONP]2.0.CO;2.

Ribeiro, M.C., Metzger, J.P., Martensen, A.C., Ponzoni, F.J., Hirota, M.M., 2009. The Brazilian Atlantic forest: how much is left, and how is the remaining forest distributed? Implications for conservation. Biol. Conserv. 142, 1141-1153. http:// dx.doi.org/10.1016/j.biocon.2009.02.021.

Rodrigues, R.R. (coordenador), 2006. Parcelas Permanentes em 40 ha de florestas do Estado de São Paulo: uma experiência multidisciplinar.

Rother, D.C., 2006. Chuva de sementes e estabelecimento de plântulas em ambientes com bambus na Mata Atlântica. Master thesis. Universidade Estadual Paulista, Rio Claro, p. 123.

Rother, D.C., Rodrigues, R.R., Pizo, M.A., 2009. Effects of bamboo stands on seed rain and seed limitation in a rainforest. For. Ecol. Manag. 257, 885-892. http:// dx.doi.org/10.1016/j.foreco.2008.10.022.

Rother, D., Jordano, P., Rodrigues, R.R., Pizo, M.A., 2013a. Demographic bottlenecks 
in tropical plant regeneration: a comparative analysis of causal influences. Perspect. Plant Biol. Syst. Evol. 15, 86-96.

Rother, D.C., Alves, K.J.F., Pizo, M.A., 2013b. Avian assemblages in bamboo and nonbamboo habitats in a tropical rainforest. Emu 113, 52. http://dx.doi.org/10.1071/ MU12017.

Santos, T., Tellería, J., 1994. Influence of forest fragmentation on seed consumption and dispersal of Spanish juniper Juniperus thurifera. Biol. Conserv. 70, 129-134. http://dx.doi.org/10.1016/0006-3207(94)90280-1.

Schupp, E.W., 1988. Factors affecting postdispersal seed survival in a tropical forest. Oecologia 76, 525-530.

da Silva, D.M., 1991. Estrutura de tamanho e padrão espacial de uma populaçao de Euterpe edulis Mart. (Arecaceae) em um Mata Mesófila Semidecídua no Município de Campinas, SP. Universidade Estadual de Campinas.

Silva, M., Martini, A., Araújo, Q., 2009. Estrutura populacional de Euterpe edulis Mart. no sul da Bahia, Brasil. Rev. Bras. Bot. 2, 393-403.

Svenning, J.C., 2001. On the role of microenvironmental heterogeneity in the ecology and diversification of neotropical rain-forest palms (Arecaceae). Bot. Rev. 67, 1-53.

Swaine, M.D., 1996. Ecology of Tropical Forest Tree Seedlings. UNESCO, Parthernon, Paris.
Tabarelli, M., Mantovani, W., 1999. Clareiras naturais e a riqueza de espécies pioneiras em uma Floresta Ombrófila Densa. Rev. Bras. Biol. 59 (2), 251-261.

Vázquez-Yánes, C., Orozco-Segovia, A., 1993. Patterns of seed longevity and germination in the tropical rainforest. Annu. Rev. Ecol. Syst. 24, 69-87.

Veloso, H.P., Oliveira Filho, L.C., 1992. Manual técnico da vegetação brasileira. Fundação Instituto Brasileiro de Geografia e Estatística, Departamento de Recursos Naturais e Estudos Ambientais. IBGE, Rio de Janeiro.

Virillo, C.B., Martins, F.R., Tamashiro, J.Y., Santos, F.A.M., 2011. Is size structure a good measure of future trends of plant populations? An empirical approach using five woody species from the Cerrado (Brazilian savanna). Acta Bot. Bras. 25, $593-600$.

Wang, Y.H., Augspurger, C., 2004. Dwarf palms and cyclanths strongly reduce neotropical seedling recruitment. Oikos 107, 619-633.

Wang, Y.H., Augspurger, C., 2006. Comparison of seedling recruitment under arborescent palms in two neotropical forests. Oecologia 147, 533-545.

Wong, K.M., 1991. The growth architecture and ecology of some tropical bamboos. J. Am. Bamboo Soc. La. 8, 43-59.

Young, S.M., Judd, W.S., 1992. Systematics of the Guadua angustifolia complex (Poaceae: Bambusoideae). Ann. Mo. Bot. Gard. 79, 737-769. 